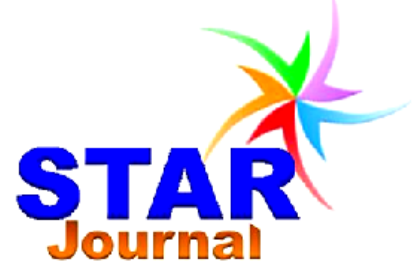

ISSN: 2226-7522(Print) and 2305-3327 (Online) Science, Technology and Arts Research Journal

July-Sep 2012, 1(3): 31-38

www.starjournal.org

Copyright $\odot 2012$ STAR. All Rights Reserved

Original Research

\title{
Fertility Desire and Reproductive Health Care Needs of Men and Women Living with HIVIAIDS in Nekemte, East Wollega, Ethiopia
}

\author{
Tesfaye Regassa ${ }^{1^{*}}$, Mesganaw Fantahun ${ }^{2}$ \\ ${ }^{1}$ College of Medical and Health Sciences, Wollega University, Post Box No: 395, Nekemte, Ethiopia \\ ${ }^{2}$ School of Public Health,Addis Ababa University, Addis Ababa, Ethiopia
}

\begin{tabular}{|c|c|}
\hline Abstract & Article Information \\
\hline \multirow{10}{*}{$\begin{array}{l}\text { Understanding fertility desire and reproductive health care needs of HIV positive men and } \\
\text { women in the era of better access to antiretroviral therapy and improved health status is } \\
\text { important in planning and organizing appropriate health services. To assess the fertility } \\
\text { desire and reproductive health care needs of men and women living with HIVIAIDS in } \\
\text { Nekemte town, East Wollega, Ethiopia. A facility based comparative cross-sectional study } \\
\text { was conducted among PLHIV both men and women from February to March } 2010 \text { on a } \\
\text { total sample of } 592 \text { respondents in Nekemte town using structured questionnaires } \\
\text { complimented by an in-depth interview. Men had higher desire to have a child than } \\
\text { women ( } 40.5 \% \text { versus } 30.7 \%) \text { Men and women who were sexually active in the six } \\
\text { months prior to survey were } 78.4 \% \text { and } 61.8 \% \text { respectively. Being male (AOR: } 1.7,95 \% \\
\mathrm{CI}: 1.1-2.8) \text {, having no living child (AOR: } 13.1,95 \% \mathrm{Cl}: 5.3-32.3) \text {, or having less than three } \\
\text { living children (AOR: } 4.2,95 \% \mathrm{Cl}: 2.2-8.0) \text {, having partner desiring child (AOR: } 15.4 \text {, } \\
95 \% \mathrm{Cl} \text { : } 9.2-25.8) \text {, CD } 4 \text { count } \geq 200 \text { (AOR: } 2.0 \text {, 95\%Cl: } 1.2-3.5) \text { were significantly } \\
\text { associated with fertility desire. Health care delivery should consider the desire for children } \\
\text { by men and women living with HIVIAIDS in order to avert preventable untoward health } \\
\text { and related consequences. }\end{array}$} & Article History: \\
\hline & Received : 18-06-2012 \\
\hline & Revised : 26-08-2012 \\
\hline & Accepted : 30-08-2012 \\
\hline & Keywords: \\
\hline & Nekemte \\
\hline & Fertility Desire \\
\hline & Health Care \\
\hline & \\
\hline & $\begin{array}{l}\text { E-mail: } \\
\text { regassatesfaye@gmail.com }\end{array}$ \\
\hline
\end{tabular}

\section{INTRODUCTION}

Globally, there were 33.3 million people living with HIV at the end of 2009 compared with 26.2 million in 1999-a $27 \%$ increase (UNIAIDS, 2010). In Ethiopia, according to calibrated single point estimates (2007), the national adult HIV prevalence was $2.1 \%(\mathrm{MOH}, 2007)$.

Most people living with HIVIAIDS are of childbearing age and face difficult choices concerning their sexuality and childbearing (Askew and Berer, 2003; USAID, 2007; WHO, 2006). As access to ART increases, HIV can be experienced as a chronic but treatable disease; PLHIV are more likely to desire children. In developed and developing countries women with HIV desiring child were $18 \%$ to $43 \%$ (Askew and Berer, 2003; WHO, 2006). In Uganda men were nearly four times more likely to desire child (Nakayiwa et al., 2006). Reports from Uganda and South Africa suggested that ART was associated with an increase in unplanned pregnancies (Myer et al., 2007; Nakayiwa et al., 2006). Thus helping men and women living with HIVIAIDS avoid unintended pregnancies is an important component of programmes to prevent mother to child transmission (PMTCT) (WHO, 2006).

Many women with HIV who are sexually active want to prevent pregnancy. Despite the desire to avoid having children, many women with HIV experience unintended pregnancies (USAID, 2007; WHO, 2006). It is critically important to assist PLHIV in both preventing unwanted pregnancies and giving birth as safely as possible knowing their desire for child. Prevention of unintended pregnancies among HIV infected women is one key strategies of PMTCT and male involvement is one important principle for PMTCT 
Tesfaye Regassa \& Mesganaw Fantahun

$(\mathrm{MOH}, 2007)$. Family planning services have great potential in promoting sexual health and in efforts to prevent and treat HIVIAIDS (Cooper et al., 2005; USAID, 2007; WHO, 2006).

In countries like Ethiopia with high prevalence of HIV, low levels of contraception and high value of childbearing, elucidating fertility desire may inform national policy decisions on PMTCT, HIV education and family planning programs (NNPWE, 2007).

People who start ART may find that, with their return to health, they become more sexually active, resume fertility desire. However, individuals found it difficult to reconcile safer sex messages with their desire to reproduce (Cooper et al., 2005; USAID, 2007; WHO, 2006).

The extent of desire of child bearing and how it varies by individual, social, health and demographic characteristics is not well understood. The desire of PLHIV both men and women to have children has implication for the transmission of HIV to sexual partners or newborns. It helps health care providers providing ART services integrated into all potential PMTCT. Thus the study tries to assess the fertility intention and reproductive health care needs of men and women living with HIVIAIDS in Nekemte town, East Wollega, Ethiopia.

\section{MATERIALS AND METHODS}

A facility based comparative cross-sectional study among PLHIV both men and women complemented by an in-depth interview was conducted from February to March 2010 in Nekemte town; located at $331 \mathrm{~km}$ to West of Addis Ababa. Total number of people on Highly Active Anti Retroviral Therapy in Nekemte hospital and health center was 1528 and 284 respectively (ARC, 2010). The study population were all men and women who had at least one visit in the selected health institutions during the study period for ART. Women and men aged 1849 years and 18-59 years respectively were eligible to participate in the study. PLHIV who were feeling severely ill, unable to hear were excluded.

Sample size was calculated based on a difference between two population proportions, using fertility desire $40.3 \%$ and $28.2 \%$ among men \& women PLHIV respectively in SNNPR (Debeko, 2007), male to female ratio of $1: 1,95 \%$ confidence level $\left(Z_{\alpha}\right), 80 \%$ power $\left(Z_{\beta}\right), 15 \%$ non-
Sci. Technol. Arts Res. J., July-Sep 2012, 1(3): 31-38

response rate. Accordingly, the estimated total sample size was 592 (296 men and 296 women). The study population was included proportional to the institutions client size. In each of the selected health facilities, participants were consecutively included in the study until the required sample size was achieved. For qualitative method equal number of men and women were interviewed till saturation of idea using purposive sampling to recruit interviewees.

The questionnaire was initially prepared in English, translated to Afan Oromo, and back to English. It was then pretested among clients from ARV units who were excluded from the final survey. For qualitative study, semi-structured questions were used to probe reasons for fertility desire moderated by the principal investigator. Note was taken by the rapporter.

Four counselors working in the ART unit administered the questionnaire after they took two days training. Two supervisors with first degree in Nursing were trained and supervised the data collection process closely.

Data were entered to EPI info, cleaned and were analyzed using SPSS version 16. Percentages were compared for men and women. Statistical significance was determined through a $95 \%$ confidence interval for fertility desire.

Responses to open-ended questions were transcribed, collapsed into dominant thematic areas to facilitate analysis. The analyses for qualitative data were done manually.

Ethical approval was obtained from the Institutional Review Board of Medical Faculty, Addis Ababa University. The purpose of the study was clearly explained, consent and confidentiality was ensured.

\section{RESULTS}

\section{Socio-Demographic Characteristics of the Study Participants}

A total of 592 PLHIV were interviewed. Men and women were each 296. Mean age for men and women was 35.3 and 30.8 years respectively. About $66 \%$ of men and $53 \%$ women respectively were married/in relationship. Regarding education, 164(55.4\%) of men and $126(42.6 \%)$ of women were attended secondary and above education. Men and women who worked in government/private employment were 
Tesfaye Regassa \& Mesganaw Fantahun

104 (35.1\%) and 56 (18.9\%) respectively. Median family income for men and women were 300 and 167.5 birr respectively (Table 1 ).

\section{Sexual Activity and Pregnancy Since Hiv Diagnosis}

Men and women who were sexually active in the six months prior to the survey were $78.4 \%$ and $61.8 \%$ respectively of which $189(81.5 \%)$ of men and $153(83.6 \%)$ of women had sex with regular partner. About $71 \%$ of men's partner were tested of which $161(77 \%)$ were positive. Among women, $187(63.2 \%)$ of their partner were tested of which $142(76 \%)$ were positive.

Twelve percent of men's partner and women reported to be pregnant after they had known
Sci. Technol. Arts Res. J., July-Sep 2012, 1(3): 31-38 their serostatus of which 25(69.4\%) and $20(55.6 \%)$ of men and women respectively reported that it was intentional.

Knowledge about HIV transmission from mother-to-baby was $99.0 \%$ and $94.9 \%$ among men and women respectively. Women and men who heard of drugs that reduces transmission of virus from mother to child were $97 \%$ of which 260 $(95 \%)$ of men and $274(96 \%)$ of women reported the drugs actually reduces transmission.

About $95 \%$ of men and women reported improvement in health status. About $65 \%$ of men \& $59.8 \%$ of women respectively had been on ART for $\leq 2$ years. Sixty five percent of men and $59.8 \%$ of women had CD4 $\geq 200$ (Table 2).

Table 1: Socio-demographic characteristics of men and women on ART in Nekemte town, Ethiopia, February 2010.

\begin{tabular}{|c|c|c|}
\hline Characteristics & $\operatorname{Men}(n=296)$ & Women $(\mathrm{n}=296))$ \\
\hline Age (years) & $n(\%)$ & $\mathbf{n}(\%)$ \\
\hline $18-29$ & $70(23.6)$ & $136(45.9)$ \\
\hline $30-39$ & $133(44.9)$ & $127(42.9)$ \\
\hline$\geq 40$ & 93(31.5) & $33(11.1)$ \\
\hline Mean (土SD) & $35.3(8.3)$ & $30.8(6.3)$ \\
\hline \multicolumn{3}{|l|}{ Educational Status } \\
\hline No education & $86(29.1)$ & $109(36.8)$ \\
\hline Primary & $46(15.5)$ & 61(20.6) \\
\hline Secondary and above & $164(55.4)$ & $126(42.6)$ \\
\hline \multicolumn{3}{|l|}{ Marital Status } \\
\hline Married/inrelationship & $195(65.9)$ & $157(53.0)$ \\
\hline widowed/divorced/separated & $65(22.0)$ & $121(40.9)$ \\
\hline never married & $36(12.2)$ & $18(6.1)$ \\
\hline \multicolumn{3}{|l|}{ Occupation } \\
\hline Daily laborer & $115(38.9)$ & $91(30.7)$ \\
\hline government/private employee & $104(35.1)$ & $56(18.9)$ \\
\hline Unemployed & $26(8.8)$ & $82(27.7)$ \\
\hline Merchant & $21(7.1)$ & $35(11.8)$ \\
\hline Farmer & $26(8.8)$ & $12(4.1)$ \\
\hline Others ${ }^{* *}$ & $4(1.4)$ & $20(6.8)$ \\
\hline \multicolumn{3}{|l|}{ Monthly Family Income(ETB) } \\
\hline No income & $35(11.8)$ & $58(19.6)$ \\
\hline less than 150 & $89(30.1)$ & $117(39.5)$ \\
\hline $151-300$ & $67(22.6)$ & $61(20.6)$ \\
\hline$>300$ & $105(35.5)$ & $60(20.3)$ \\
\hline Median & 300 & 167.5 \\
\hline
\end{tabular}


Table 2: Sexual activity and HIV related information of men and women living with HIV in Nekemte town, East Wollega, Ethiopia, February 2010.

\begin{tabular}{|c|c|c|}
\hline Characteristics & $\begin{array}{l}\text { Men } \\
\mathrm{n}(\%) \\
\end{array}$ & $\begin{array}{c}\text { Women } \\
\mathbf{n}(\%)\end{array}$ \\
\hline Sexually active in the last sixth months & $n=296$ & $n=296$ \\
\hline Yes & $232(78.4)$ & $183(61.8)$ \\
\hline No & $64(21.6)$ & $113(38.2)$ \\
\hline Sex with whom? & $\mathrm{n}=\mathbf{2 3 2}$ & $n=183$ \\
\hline Regular partner & $189(81.5)$ & $153(83.6)$ \\
\hline None regular partner(casual) & $39(16.8)$ & $26(14.2)$ \\
\hline No response & $4(1.7)$ & $4(2.2)$ \\
\hline Partners tested & $n=296$ & $n=296$ \\
\hline Yes & $209(70.6)$ & $187(63.2)$ \\
\hline No & $57(29.4)$ & $44(36.8)$ \\
\hline Partners HIV status & $n=209$ & $n=187$ \\
\hline Positive & $161(77)$ & 142(76) \\
\hline Negative & $48(23)$ & $45(24)$ \\
\hline Sexual desire & $\mathrm{n}=296$ & $n=296$ \\
\hline No change & $135(45.6)$ & $165(55.7)$ \\
\hline Decreased & $99(33.4)$ & $93(31.4)$ \\
\hline Increased & $62(20.9)$ & $27(9.1)$ \\
\hline No Response & $0(.0)$ & $11(3.7)$ \\
\hline $\begin{array}{l}\text { Pregnancy or partner pregnancy since HIV } \\
\text { diagnosis }\end{array}$ & $\mathrm{n}=\mathbf{2 9 6}$ & $\mathrm{n}=\mathbf{2 9 6}$ \\
\hline Yes & $36(12.2)$ & $36(12.2)$ \\
\hline No & $260(87.8)$ & $260(87.8)$ \\
\hline Was it intentional pregnancy? & $n=36$ & $n=36$ \\
\hline Yes & $25(69.4)$ & $20(55.6)$ \\
\hline No & $11(30.6)$ & $16(44.4)$ \\
\hline HIV transmit from mother to child & $n=296$ & $n=296$ \\
\hline Yes & $281(94.9)$ & 293(99.0) \\
\hline No & $15(5.1)$ & $3(1.0)$ \\
\hline $\begin{array}{l}\text { Attitude toward drug given to reduce MTCT } \\
\text { actually reduces transmission }\end{array}$ & $n=273$ & $n=285$ \\
\hline Yes & $260(95)$ & $274(96)$ \\
\hline No & $12(4)$ & $10(4)$ \\
\hline Don't know & $1(.7)$ & $1(.3)$ \\
\hline Self reported changes in health & $n=296$ & $n=296$ \\
\hline Improved & $279(94.3)$ & $281(94.9)$ \\
\hline Not improved & $17(5.7)$ & $15(5.1)$ \\
\hline Duration of time on ART(in years) & $n=296$ & $n=296$ \\
\hline$\leq 2 \mathrm{yrs}$ & 192(64.9) & $177(59.8)$ \\
\hline$>2 y r s$ & $104(35.1)$ & $119(40.2)$ \\
\hline Recent CD4 count (cells $/ \mathrm{mm}^{3}$ ) & $\mathrm{n}=296$ & $\mathrm{n}=296$ \\
\hline$<200$ & 192(64.9) & $177(59.8)$ \\
\hline$\geq 200$ & $104(35.1)$ & $119(40.2)$ \\
\hline
\end{tabular}

\section{Fertility Desire of Men and Women}

Forty one percent of men and $30.7 \%$ of women wanted to have a child of which $71 \%$ of men and $69 \%$ of women respectively were not decided when to have a child. Reasons for desiring a child among men and women were wanting more children (56 (47\%) and 45 (49\%) respectively) followed by the desire to have at least one child 48(40\%) and 41 (45\%) respectively (Table 3 ). 
Table 3: Fertility intentions of men and women living with HIVIAIDS on ART in Nekemte town, East Wollega, Ethiopia, February 2010.

\begin{tabular}{|c|c|c|}
\hline Characteristics & Men (\%) & Women (\%) \\
\hline Number of alive children & $\mathrm{n}=\mathbf{2 9 6}$ & $n=296$ \\
\hline No living child & $73(24.7)$ & $68(23.0)$ \\
\hline $1-2$ & $139(47.0)$ & $128(43.2)$ \\
\hline$>2$ & $84(28.4)$ & $100(33.8)$ \\
\hline \multicolumn{3}{|l|}{ Want to have child } \\
\hline Yes & $120(40.5)$ & $91(30.7)$ \\
\hline No & $176(59.5)$ & $205(70.3)$ \\
\hline When do you desire to have a child? & $\mathrm{n}=120$ & $\mathrm{n}=91$ \\
\hline Within next 12 months & $12(10)$ & $9(10)$ \\
\hline within one to three years & $21(18)$ & $15(16)$ \\
\hline after three years & $2(2)$ & $5(5)$ \\
\hline Not decided when to have a child & $85(71)$ & $62(68)$ \\
\hline Reason for their current fertility desire & $\mathrm{n}=120$ & $\mathrm{n}=91$ \\
\hline Want at least one child & $48(40)$ & $41(45)$ \\
\hline I did not have desired number & $56(47)$ & $45(49)$ \\
\hline Desire of partner, family & $10(8)$ & $3(3)$ \\
\hline Others* & $12(10)$ & $5(5)$ \\
\hline Reason not to desire a child & $n=176$ & $n=205$ \\
\hline Already achieved desired number of child & $89(51)$ & $107(52)$ \\
\hline Fear of mother to child transmission of HIV & $24(14)$ & $25(12)$ \\
\hline Don't have adequate income & $31(18)$ & $29(14)$ \\
\hline $\begin{array}{l}\text { Child bearing may further compromise my } \\
\text { health }\end{array}$ & $16(9)$ & $27(13)$ \\
\hline May not be healthy in future to care for child & $8(5)$ & $14(7)$ \\
\hline Fear of orphaning/problems in caring & $11(6)$ & $15(7)$ \\
\hline Fear of infecting partner while try to conceive & $12(7)$ & $2(1)$ \\
\hline Preferred sex for those with fertility desire & $n=120$ & $\mathrm{n}=91$ \\
\hline Male & $20(17)$ & $10(11)$ \\
\hline Female & $3(3)$ & $7(8)$ \\
\hline No preference(God knows) & $97(81)$ & $74(82)$ \\
\hline Desire of a partner to have a child & $n=296$ & $n=296$ \\
\hline Yes & $105(35.5)$ & $80(27.0)$ \\
\hline No & $146(49.3)$ & $143(48.3)$ \\
\hline Don't have a partner & $45(15.2)$ & $73(24.7)$ \\
\hline Contraceptive use & $\mathrm{n}=296$ & $\mathrm{n}=296$ \\
\hline Yes & $216(73.0)$ & $180(60.8)$ \\
\hline No & $80(27)$ & $117(39.5)$ \\
\hline Contraceptive method & $n=216$ & $n=180$ \\
\hline Condom & $211(97.7)$ & $176(97.8)$ \\
\hline Injectable & $18(8.3)$ & $14(7.8)$ \\
\hline Pills & $2(0.9)$ & $3(1.7)$ \\
\hline IUD/ Implants & $4(1.6)$ & $2(1.2)$ \\
\hline
\end{tabular}

* For substitution, children are an important part of marriage, current child needs sibling, original desires for childbearing unchanged.

The qualitative result indicated that, out of 10 respondents, most had children. Discussion of their fertility desire elicited multiple fears: child would be born HIV-positive, risk of re-infection with a new strain or transmission of HIV to partner while trying to conceive. However, few out of those with children and all of those without children expressed their desire to have child, 
Tesfaye Regassa \& Mesganaw Fantahun

justified by not having any child, availability of PMTCT, improvements of health status.

A 24 years old never married man, "I don't have any child. If I have a child, I will be happy and having a child is very important---If I get a child, I consider myself as I am in heaven. --- I have not decided how many children I will have but I have a great desire to have a child."

Seventy three percent of men or their partner and $60.8 \%$ of women were using at least one modern contraceptive method of which $211(97.7 \%)$ and $176(97.8 \%)$ respectively were using condom (Table 3 ).

In bivariate model, male (AOR:1.5, 95\% Cl:1.12.2) , family size $\leq 2$ (AOR:3.7, 95\%Cl:2.5-5.3), not disclosing to family (AOR:2.0, 95\%Cl:1.3-
Sci. Technol. Arts Res. J., July-Sep 2012, 1(3): 31-38

3.2), no living child (AOR:11.0, 95\% Cl:6.4-18.8), 1-2 living children (AOR:4.2, 95\%Cl:2.6-6.7), partner's desire (AOR:12.3, 95\% Cl:8.1-18.5), CD4 count $\geq 200$ (AOR:1.9, 95\%Cl:1.2-2.8), $\leq 2$ years since diagnosed for HIV (AOR:.6, 95\% Cl:.4 $-.8), \leq 2$ years since started ART(AOR:.7, $95 \% \mathrm{Cl}: .5-.9)$ were significantly associated with fertility desire.

In a multivariate model, male (AOR:1.7, 95\%Cl:1.1-2.8), 18-29 years (AOR:3.5, 95\%Cl: 1.6-7.4), 30-39 years (AOR:3.0, 95\%Cl:1.5-6.0), having no living child (AOR:13.1, 95\%Cl:5.332.3), having 1-2 living children (AOR:4.2, $95 \% \mathrm{Cl}: 2.2-8.0)$, having partner desiring child (AOR:15.4, 95\%Cl:9.2-25.8), $\mathrm{CD}_{4}$ count $\geq 200$ (AOR:2.0, 95\%Cl:1.2-3.5) were significantly associated with fertility desire (Table 4).

Table 4: Factors associated with fertility desire of people living with HIVIAIDS on ART in Nekemte town, East Wollega, Ethiopia, February 2010.

\begin{tabular}{|c|c|c|c|c|}
\hline Characteristics & $\begin{array}{l}\text { Desired } \\
\text { child (n) }\end{array}$ & $\begin{array}{l}\text { Not Desired } \\
\text { child (n) }\end{array}$ & Crude OR(95\% Cl) & Adjusted OR(95\% Cl) \\
\hline \multicolumn{5}{|l|}{ Sex } \\
\hline Female & 91 & 205 & 1 & 1 \\
\hline Male & 120 & 176 & $1.5(1.1,2.2)^{*}$ & $1.7(1.1,2.8)^{*}$ \\
\hline \multicolumn{5}{|l|}{ Age } \\
\hline $18-29$ & 101 & 105 & $5.5(3.2,9.7)^{*}$ & $3.5(1.6,7.4)^{*}$ \\
\hline $30-39$ & 91 & 169 & $3.0(1.7,5.2)^{*}$ & $3.0(1.5,6.0)^{*}$ \\
\hline$\geq 40$ & 19 & 107 & 1 & 1 \\
\hline \multicolumn{5}{|l|}{ Family Size } \\
\hline$\leq 2$ & 104 & 73 & $3.7(2.5,5.3)^{*}$ & $1.5(.8,3.0)$ \\
\hline$>2$ & 107 & 308 & 1 & 1 \\
\hline \multicolumn{5}{|l|}{$\begin{array}{l}\text { Disclosure To } \\
\text { Family }\end{array}$} \\
\hline Yes & 165 & 335 & 1 & 1 \\
\hline No & 46 & 46 & $2.0(1.3,3.2)^{*}$ & $1.6(.9,3.0)$ \\
\hline \multicolumn{5}{|l|}{$\begin{array}{l}\text { Number of Alive } \\
\text { Children }\end{array}$} \\
\hline $\begin{array}{l}\text { no living } \\
\text { child }\end{array}$ & 93 & 48 & $11.0(6.4,18.8)^{*}$ & $13 \cdot 1(5 \cdot 3,32 \cdot 3)^{*}$ \\
\hline $1-2$ child & 96 & 171 & $4.2(2.6,6.7)^{\star}$ & $4.2(2.2,8.0)^{\star}$ \\
\hline$>2$ & 22 & 162 & 1 & \\
\hline \multicolumn{5}{|l|}{ Partner's Desire } \\
\hline Yes & 136 & 49 & $12.3(8.1,18.5)^{*}$ & $15.4(9.2,25.8)^{*}$ \\
\hline No & 75 & 332 & 1 & 1 \\
\hline \multicolumn{5}{|l|}{$\begin{array}{l}\text { Recent CD4 } \\
\text { Count }\end{array}$} \\
\hline$<200$ & 39 & 113 & 1 & 1 \\
\hline$\geq 200$ & 172 & 268 & $1.9(1.2,2.8)^{*}$ & $2.0(1.2,3.5)^{\star}$ \\
\hline \multicolumn{5}{|l|}{$\begin{array}{l}\text { Duration Since } \\
\text { Diagnosis }\end{array}$} \\
\hline$\leq 2$ years & 128 & 197 & 1 & 1 \\
\hline$>2$ years & 83 & 184 & $.6(.4, .8)^{*}$ & $1.3(.6,3.0)$ \\
\hline \multicolumn{5}{|l|}{ Duration on ART } \\
\hline$\leq 2$ years & 149 & 220 & 1 & 1 \\
\hline$>2$ years & 62 & 161 & $.7(.5, .9)^{*}$ & $.6(.2,1.4)$ \\
\hline
\end{tabular}


Tesfaye Regassa \& Mesganaw Fantahun

\section{DISCUSSION}

These findings showed nearly one third of women and men living with HIV in Nekemte town desired to have children $(30.7 \%$ and $40.5 \%$ respectively). The study was consistent with cross sectional study from South Africa (50\% of men and $45 \%$ of women) (Cooper et al., 2005).

In Uganda, $16 \%$ of HIV-infected men and women desired more children. Men were almost four times more likely to want children than women $(27 \%$ vs. $7 \%)$ (Nakayiwa et al., 2006). The desire among women was consistent with cross sectional study from South Africa (29\%) (Myer et al., 2007). A similar pattern of fertility desire was observed in the 2005 Ethiopian Demographic and health surveys except that a relatively higher proportion among both males and females $(65.1 \%$ and $58.1 \%$ respectively) (EDHS, 2005). Men's greater desire may be due to a desire to leave something of themselves, their 'name' and lineage behind when they die. Thus it is important that it helps policy makers and health care providers to involve men more in prevention of pregnancy for those not desiring a child and education of the efficacy of prevention of transmission from mother to child.

Seventy eight percent among men and $61.8 \%$ among women were sexually active in the 6 months prior to survey. It was found consistent with Brazil study, sexual encounter per month had increased from $60 \%$ initially to $78 \%$ in two years on ART (USAID, 2007). Many PLHIV continue to be sexually active and some had strong desire children (Cooper et al., 2009; Myer et al., 2007) which entails unprotected sexual intercourse.

In the current study, $23 \%$ of respondent's partners were found HIV negative. If the woman is infected and the man is not, artificial insemination would avoid the risk of transmitting HIV to him. When a man has HIV and his partner does not, the only way to avoid the risk of transmitting HIV is artificial insemination using semen from a donor who does not have HIV (USAID, 2007). But in resource poor setting like ours, those interventions are difficult.

This finding also indicated that among $12 \%$ of men, their partner became pregnant since they knew their serostatus (69.4\% was intentional). Also $12 \%$ of women became pregnant $(55.6 \%$ intentional). It was consistent with the report from South Africa (9\%); of those $70 \%$ of pregnancies were reportedly intentional (Cooper et al., 2009) while slightly lower than study found from Uganda
Sci. Technol. Arts Res. J., July-Sep 2012, 1(3): 31-38

among women on ART (16.9\%) (Homsy, et al., 2009). Prevention of unwanted pregnancies avoids many births of HIV-infected infants (Cooper et al., 2009; Reynolds et al., 2005; USAID, 2007). Interventions to address these gaps are needed both in the broader $\mathrm{RH}$ services and within HIV care settings targeting men too.

Seventy three percent of men and $60.8 \%$ of women were using at least one modern contraceptive method. It is estimated that onefourth of all births in sub-Saharan Africa are unintended. Meeting the family planning needs of all women with HIV in sub-Saharan Africa has the potential to avert 120,000 HIV-positive births each year (Reynolds et al., 2005).

Combined interventions such as ARV medications, cesarean section delivery, and avoidance of breastfeeding have been able to reduce the risk of mother-to-child transmission of HIV in developed countries to below $2 \%$ (USAID, 2007). However, in developing countries with low income only few people access to the necessary services due to economic constraint. Thus helping those who do not want to have a child preventing unintended pregnancies is a cost effective.

Younger age has consistently been associated with fertility desire in studies of HIV-positive people in South Africa and Ethiopia (Cooper et al., 2009; NNPWE, 2007; Tamene and Fantahun, 2007; WHO, 2006). Many people who are diagnosed with HIV during their reproductive years inevitably face tough decisions about their reproductive future. Addressing the $\mathrm{SRH}$ needs of all young people, including those with HIV (USAID, 2007) has public health importance as many new HIV infections in Ethiopia are occurring in younger women and men.

In current study among both men and women fertility desire is associated with partners desire to have a child. It was consistent with South Africa and Addis Ababa studies (Cooper et.al, 2005, Tamene and Fantahun, 2007). This indicates contraceptive and PMTCT information have to involve their partner as well.

Patients with $\mathrm{CD}_{4}$ count $(\geq 200$ cells $/ \mathrm{mm} 3$ ) desired to have child. Having $\mathrm{CD}_{4}$ cell count $>500$ was associated fertility desire in Uganda (Homsy et al., 2009). It may be due to the improvement of health status increases the commitment of these people to achieve their reproductive desires.

The strengths of this study is it provides insights on the fertility desire and associated 
Tesfaye Regassa \& Mesganaw Fantahun

health care needs of men living with HIV that $\mathrm{SRH}$ services must target men too. Concerning its limitations, self-reported data are difficult to validate, and may be influenced by socially desirable responses; however, an effort has been exerted to minimize this by training interviewers.

\section{CONCLUSION}

Study reveals that $40.5 \%$ of men and $30.7 \%$ women desired a child. Being male, younger age, not having alive child, having 1-2 living children, having a partner desiring a child, $\mathrm{CD}_{4}$ count $\geq 200 / \mathrm{mm} 3$ were the predictors of fertility desire. Heath services organizations should consider the desire for children by men and women living with HIVIAIDS in order to avert preventable untoward health and related consequences.

PLHIV who do not want to have a child require effective contraception. Those who desire child and engaged in pregnancy risk behaviour need education on the efficacy of PMTCT. Those who desire child and not engaged in pregnancy risk behaviour need on-going counseling. HIV care and treatment could provide an important opportunity to provide information and counseling to men that would encourage their involvement more in reproductive health services.

Advice is needed from health care workers on how to balance safer sex practices and the desireto reproduce and effective contraceptive method for those not desiring a child; condom plus other contraceptive.

\section{ACKNOWLEDGMENTS}

We acknowledge the EPHA/CDC for funding this research project. It gives us a great honor to thank all study participants for their cooperation in providing the necessary information.

\section{REFERENCES}

ARC (2002 E.C). Monthly HIV Care and ART Update, Update as of end of Yekatiti. Accessed February, 2010, from www.etharc.org <http://www.etharc.org >.

Askew, I. and Berer, M. (2003). The Contribution of Sexual and Reproductive Health Services to the Fight agaist HIVIAIDS: A Review. Reproductive Health Matters 11(22):51-73.

Cooper, D., Bracken, H., Myer, L., ZweigenthaL, V., Harries, J., Orner, P., Manjezi, N. \& Ngubane, P. (2005). Policy brief; Reproductive intentions and choices among HIV-infected individuals in Cape Town, South Africa: Lessons for reproductive policy and service provision from a qualitative study. Cape Town, University of Cape Town.
Sci. Technol. Arts Res. J., July-Sep 2012, 1(3): 31-38

Cooper, D., Moodley, J., Zweigenthal, V., Bekker, L.G., Shah, I. \& Myer, L. (2009). Fertility Intentions and Reproductive Health Care Needs of People Living with HIV in Cape Town, South Africa: Implications for Integrating Reproductive Health and HIV Care Services. AIDS Behaviour 3(supplement): 38-46.

DEBEKO, K. (2007) . Sexual and reproductive health needs and preferences of people living with HIVIAIDS in Southern Nations Nationalities and Peoples Region, MPH thesis, Addis Ababa University, Addis Ababa.

EDHS (September 2006). Ethiopia demographic and health Survey 2005. Addis Ababa, Ethiopia.

Homsy, J., Bunnell, R., Moore, D., King, R., Malamba, S., Nakityo, R., Glidden, D., Tappero, J. \& Mermin, J. (2009). Reproductive Intentions and Outcomes among Women on Antiretroviral Therapy in Rural Uganda: A Prospective Cohort Study. PLOS ONE, 4.

MOH (July 2007). Guidelines for Prevention of Motherto-Child Transmission of HIV in Ethiopia, Federal HIVIAIDS Prevention and Control Office. Addis Ababa, MOH.

Myer, L., Morroni, C. \& Rebe, K. (2007). Prevalence and Determinants of Fertility Intentions of HIVInfected Women and Men Receiving Antiretroviral Therapy in South Africa. AIDS PATIENT CARE and STDs 21(4): 278-285.

Nakayiwa, S., Abang, B., Packel, L., Lifshay, J., Purcell, D. W., King, R., Ezati, E., Mermin, J., Coutinho, A. \& Bunnell, R. (2006). Desire for Children and Pregnancy Risk Behavior among HIVInfected Men andWomen in Uganda. AIDS Behaviour 10(supplement): 95-104.

NNPWE (July 2007). National Network of Positive Women Ethiopians (NNPWE). Addis Ababa, NNPWE.

Reynolds, H. W., Steiner, M. J. \& Cates, W. (2005). Contraception's proved potential to fight HIV. Sex Transmission Infection 81(5): 180-188.

Tamene, W. \& Fantahun, M. (2007). Fertility desire and family planning demand among HIV positive women and men undergoing treatment in Addis Abba, Ethiopia. African Journal of AIDS research 6 (3):223-227.

UNIAIDS (2010). UNAIDS Report On The Global Aids Epidemic. Geneve, UNIAIDS.

USAID (2007). Family Planning Choices for Women with HIV, Population report, John Hopkins Bloomberg school of Public Health.

WHO (2006). Sexual and reproductive health of women living with HIVIAIDS. Guidelines on care, treatment and support for women living with HIVIAIDS and their children in resource-constrained settings. Geneva 27, Switzerland, WHO. 